\title{
Role of Ayush in India's Battle with COVID 19 Pandemic: A Review
}

\author{
Neeru Sharma ${ }^{1}$, Arun Sharma ${ }^{1}$, Yadevendra Yadav ${ }^{2}$, Khem Chand Sharma ${ }^{3 *}$ \\ ${ }^{1}$ P. G. Scholar, P. G. Department of Rasa Shastra evum Bhaishajya Kalpana, Uttarakhand Ayurved University, Rishikul Campus, Haridwar \\ ${ }^{2}$ Assistant Professor, P. G. Department of Rasa Shastra evum Bhaishajya Kalpana, Uttarakhand Ayurved University, Rishikul Campus, Haridwar \\ ${ }^{3}$ Professor and H. O. D, P. G. Department of Rasa Shastra evum Bhaishajya Kalpana, Uttarakhand Ayurved University, Rishikul Campus, Haridwar
}

\begin{abstract}
DOI: $10.36348 /$ sijtcm.2020.v03i08.002
| Received: 19.09.2020 | Accepted: 26.09.2020 | Published: 30.09.2020

*Corresponding author: Khem Chand Sharma
\end{abstract}

\section{Abstract}

The coronavirus disease 19 (COVID-19) pandemic is unique and unprecedented in several aspects and has challenged health care systems. It is a worldwide epidemic that creates panic all over the world. So this is a very critical time. This the time to mainstreaming the AYUSH systems to transform Indian healthcare and demonstrate the potential of AYUSH systems in addressing the challenge and restoring health. In India, the world's oldest existing health care system originated. Therefore, it is carefully watched by the world community for how it handles the crisis using its resources. Ayurveda has enough potential and possibilities to be employed both for the prevention and treatment of COVID19. Charaka Samhita, an essential classical textbook of Ayurveda, describes Janpadiwansa (epidemic) management and defines immunity as the ability to prevent disease. Through Yoga, Meditation, Aasana, Pranayama, we can strengthen our immune system, including our Pranavaha Srotas, our respiratory system. The clapping sound is a kind of Marma therapy \& Music therapy. Various Rasayana medicines are used for rejuvenation \& improving immunity in Ayurveda. Rising tolls of COVID-19 positive cases and deaths possibly raise anxiety and stress, while depressive and loneliness feelings are likely due to mandatory social distancing measures. Ayurvedic herbs i.e., Ashwagandha, Guduchi, Yasthimadhu, Pippali proved to be beneficial to help fight against the virus. Several steps for mental health are described, which have a potential role in engaging the community in creating a more positive, healthy environment.

Keywords: Pranavaha srotas, Rasayana, Prayanama.

Copyright (C) 2020 The Author(s): This is an open-access article distributed under the terms of the Creative Commons Attribution 4.0 International License (CC BY-NC 4.0) which permits unrestricted use, distribution, and reproduction in any medium for non-commercial use provided the original author and source are credited.

\section{INTRODUCTION}

COVID- 19, the recent virus outbreak declared as Pandemic by WHO [1] threatened the world by its fast-spreading nature and created an alarming situation worldwide. However, the implementation of prophylactic strategies such as promoting hygiene, social distancing, and global lockdown, the spread of disease remains a challenge. The healthcare system around the world has been posed with an unprecedented challenge by this pandemic. In the wake of the COVID19 outbreak, entire humanity across the globe are suffering. Enhancing the body's natural defense system (immunity) plays a vital role in maintaining optimum health. As the battle with coronavirus seems to be very lengthy, it is worthy of empowering immunity to keep the disease away. The infection was transmitted to people through unidentified intermediary creatures in Wuhan, Hubei territory, China, in December 2019, which has a specific beginning in bats. The restricted freedom and the panic situation cause fear, anxiety, behavioral issues, domestic abuse, interpersonal relationship issues, financial crisis, separation anxiety, withdrawal symptoms resulting from non-availability of alcohol, increased violence against women, etc. are also reported throughout the globe. In the middle age group, they have raised future concerns resulting from the job insecurities and almost resultant financial crisis. Livings away from home in such situations create separation anxiety among them and also interpersonal relationship issues. Although the different types of cultures in society, all are affected in an almost equal manner. Worshipping areas are the places of mass gatherings and bounded to the lockdown; hence it affects all the religions. Such a pandemic as COVID 19 is having an inevitable impact on the mind of the people throughout the world.

COVID-19 can be placed under Pranavaha Srotas diseases according to its sign and symptoms. Charaka Samhita, the classic of Ayurveda, describes epidemic management and defines immunity as the ability to avoid infectious disease and arrest its progress to maintain homeostasis [2]. The distinguishing feature 
of Ayurveda in increasing body strength is the utilization of simple daily ways, most of which are without medicines. As COVID-19 is a pandemic, Ayurveda considers it as a Janapadodhwansa. Means death of many people occurs at the same time though they have different Prakruti, Aahara, Deha, Bala, Satmya, Satva, Vaya [3]. It is also Samsargaj Roga, i.e., the disease which is communicable due to a history of contact with an affected person. Yoga and Ayurveda, as add-on therapy, may support patients of COVID-19 by improving the quality of standard care.

\section{Virus Overview}

The term coronavirus derives from the Latin word corona, which means crown or halo as virus particles display a crown-like fringe typically referred to as spikes. A group of spherical or pleomorphic enveloped RNA viruses, carrying petal or club-shaped pleomorphic on their surface, has been classified as Corona viruses [4]. Previous outbreaks of coronaviruses (CoVs) include severe acute respiratory syndrome (SARS)-CoV. SARS spreads by inhalation of the virus present in droplets or aerosols of respiratory secretions of patients. The chest radiograph shows pneumonic changes. Death is due to respiratory failure [5]. The beginning of symptoms is usually within 14 days (2-14 days) of exposure. At present, confirmation of cases of COVID-19 is based on real-time reverse transcriptasepolymerase chain reactions (RT-PCR) with confirmation by nucleic acid sequencing [6]. COVID19 patients can discharge from the hospital if they show two negative PCR samples from the throat within $24 \mathrm{hrs}$ [7].

\section{Transmission}

Several reports have suggested that person-toperson transmission is a likely route for spreading COVID-19 infection. This fact is supported by cases that occurred within families and among people who did not visit the wet animal market in Wuhan. Personto-person transmission occurs primarily via direct contact or through droplets spread by coughing or sneezing from an infected individual.

\section{Possible aspects of Ayurvedic preventive measure and management for COVID-19}

Ayurvedic treatments may not help to cure coronavirus infection. But the Ayurvedic holistic approach to keep the health of a healthy person, which we can say indirectly to prevent developing diseases, is the key to this pandemic. According to the survey of WHO, approximately 4 billion people $(80 \%)$ of the world currently depend on herbal medicine(s) for some aspect of primary health care [8]. Acharya Sushruta emphasizes that the sum of all kinds of Chikitsa (Medical treatment) in a particular disease is Nidanparivarjan i.e., by removing the Karan or Hetu (Cause), the manifestation of the infection get dissolved itself [9]. It means we should follow the rule of social distance, means should not touch or remain close to the diseased person, avoid dining, sitting with the infected person, to prevent droplet infection, we should keep covering the mouth, should not share clothes, cosmetics with the diseases person. In Ayurveda, the main reason of Janapadodwamsa is Adharma (sinful or unwholesome acts), and it was mostly due to three factors like Asatmedriya samyoga (unwholesome conjunction of sense organs and objects), Pragyaparadha (making errors intentionally), and Parinama (consequences). Hence, Acharya Charaka has stressed in pandemics more on Sadvritta to bring the conjoined balance of three factors.

Acharya Sushruta mentioned that change of place and performing the Homa (oblation) etc. in the pandemics [10]. Hence Homa can be indicated for the correction of the Vikruta Vayu and Desha. Homa is a spiritual ritual, and scientifically can be understood as one type of Dhupana (fumigation). In this procedure, the heat and fumes/gases generated by Dhupana may sterilize the air. It may prevent the spreading of COVID-19 from one person to another person through contaminated air. For this, some of the readily available herbs/drugs in Dashanga Dhupana [11] and also the medications like Tulsi or holy basil (Ocimum basilicum) and Haridra or turmeric (Curcuma longa) can use in fumigation.

Vyayama (exercise) should be practiced by every individual at their strength/capacity. The Abhyanga (oil massage) for at least 5 to 10 minutes by lukewarm Tila Taila (Sesame oil) or Bala Taila or Ksheera Bala Taila. Doing regularly Snana (bathing) with lukewarm water by mixing with Neem leaves decoction and Vastra Dharana (dressing) by changing the clothes every day or after coming from outside. Practicing these procedures regularly has various effects on the body. In COVID-19, these are more useful indirectly in the prevention of the disease.

Satvavajaya chikitsa is to be performed in the psychologically affected subjects in a stepwise manner. This includes Gyana (knowledge of self), Vijnana (scientific reasoning), Dhairya (determination or patience), Smrithi (application of recollections or memory), and Samadhi (attaining a stable state of mind) [12]. Guyana, knowledge of self is provided, i.e., creating awareness of how one has to perform or react in such an unfamiliar situation of the pandemic. Involve in stress-relieving activities such as reading, breathing exercises, or any other hobbies according to one's interest. $\mathrm{Be}$ in touch with relatives and close friends over the phone or social media, and always keep the mind open. In the step of Dhairya (Determination or patience), i.e., develop the patience to stick on to the rules for a better future. Have the determination to obey rules such as lockdown, social distancing, and hygienic measures for possible prevention. 
In the step of Smrithi (application of recollections or memory), i.e., recollect the previous victories over such pandemics and pertain. In the stage of Samadhi (attaining a stable state of mind) i.e., Steps to have a steady state of mind, which is to be done as per the advice from the experts in this regard. Practice relaxation postures such as Savasana after exercises. Chanting of mantras may also be tried to improve concentration.

Rasayan dravyas (immune-modulator drugs) of Ayurveda can use for health promotion, immunemodulation, prevention, and reduce the disease burden from COVID-19. Drugs such as Ashwagandha (Withania somnifera L. Dunal), Guduchi (Tinospora cordifolia Willd. \& Miers), Amalaki (Phyllanthus emblica L.), Mulethi (Glycyrrhiza glabra L.), Shatavari (Asparagus racemosus Willd.), Chirayta (Andrographis paniculata (Burm.f.) Nees), Tulsi (Ocimum sanctum L.), Punarnava (Boerhaavia diffusa L.) and Pippali (Piper longum L.)

The preventive aspect of management aims to maintain the health of a healthy individual and improving disease resistance capacity, which are vital factors in the management of COVID-19. For achieving this, Agni (the energy responsible for metabolism and transformation) and Bala (innate/acquired strength and immunity) restoration are essential factors. These can achieve by proper use of Aahara (food and its habits), Vihara (lifestyles), and administration of various Oushadhis (medicines), Rasayanas as well as Panchkarma.

Acharaya Charaka emphasizes that food is one of three supporting pillars of life [13] and described it as Mahabheshajam [14]. Aahara improves vitality, strength, complexion, and Ojas (immunity), and none of the medications can be equivalent to Ahara [15].

Pranayama includes several types of Yoga, which are related to respiration such as Bhastrika (forceful fast breathing), Anuloma-Viloma (sequential breathing by alternate closing of each nostril), Ujjayi (ocean breath), Sitali (the cooling breath), etc. All these Pranayam help clean the excess mucus accumulated in bronchial alveoli and helps in increasing their elasticity. It means Pranayama is a tool to increase total lung capacity [16]. In the case of COVID-19, SARS is a severe manifestation that is the cause of death. Therefore claim can be made that a person is likely to manifest SARS to a less severe extent if he/she have better lung capacity. This will give a chance and enough time to manage COVID-19 by the available medications and life-saving care. Hence it can be strongly advisable to include Pranayama in preventive strategies suggested for COVID-19. Meditation is effective in reducing inflammation markers and influence markers of a virus-specific immune response [17].
Strengthening Psychological Immunity by Cognitive aspects

Nourishing the mind with positive, constructive ideas that build strong belief that the quality of thoughts affects the quality of the body. Motivation aspects, i.e., gratitude for what you are, since that the grateful heart is always satisfied with its condition, which keeps the immune system calm and vital processes inside. Hence, it works in its best form. Behavioral aspects, i.e., doing meditation for at least thirty minutes per day increases confidence,

\section{Preventive Management Steps}

I. Maintain personal hygiene.

II. Wash your hands often with toilet soap and water for at least 20 seconds, if soap and water are not available.

III. Avoid touching your mouth, nose, and eyes with a non-sanitize hands.

IV. Avoid close contact with people who have coryza or flu-like symptoms.

V. Stay home when you feel sick.

VI. Cover your face during cough or sneeze and wash your hands after coughing or sneezing, and disinfect frequently touched objects and surfaces.

Low mental health status, including stress and depression, is known to increase the risk of acute respiratory infections [18].

\section{Traditional recipes followed in various parts of India}

In Indian cuisine contains many spices have great medicinal value, and uses of seasonal vegetables are work as preventive \& therapeutic medicine. Turmeric, piper, Ginger, cumin, cinnamon, clove, and bay leaf are the ingredient of all curry and soups. Hot buttermilk, gram flour sour soup, and gram flour dessert are used in acute rhinitis and flu. Masala tea is used in every cover of India. Use of packed and junk food is very limited to a fraction of the cities population. Some traditional medicinal and Dietary home-made preparations are being used in many parts of India to reduce the chances of diseases caused by infectious. Oushadha Kanji, a unique medicinal porridge consumed in the Southern part of Indian during the rainy season, which is common as a traditional beverage consumed in July and August. This is an exceptional fermented food based on the principles of Ayurveda, which is suitable for all age groups people, as it would act as a detoxifying agent and helps to improve the immunity of the body. The unique combination of spices, herbs, and rice in this dish is expected to keep fevers occurs during the rainy season at bay and positively affect some of the common diseases of the rainy season. In summer, in southern states of India, Karingal vellam, which is colored and warm water, is served with food. It prepares with water infused with herbal spices. After the meal, it would be 
Ginger infused water and Cumin seeds. The practice of consuming luke water ensures that it is made safe for intake after boiling.

\section{CONCLUSION}

From the above, we can reveal that the diet and lifestyle which were described thousands of years ago in the classical texts of Ayurveda are beneficial, and one can follow it for prevention of COVID-19. By adopting such preventive as well as curative measures mentioned in the Ayurvedic classics, we may be capable of leading a life with a positive physical as well as mental health. Rasayana, due to its multidimensional activity, performs as a substance that is responsible for taking care of body, mind, and spirit and thus affecting total wellbeing. There is not any doubt that India very densely populated country in the world, with poor knowledge of personal and social hygiene and have average health care infrastructure. Still, the mortality rate might be lower than developed countries because, in India, a large subset of the population depends upon the traditional system of medicine and home remedies. Also, the immunity of Indian is good due to their food habits and daily routine based on circadian rhythm. Recognizing the value of Ayurveda, the Ministry of health, in an association of the ministry of Ayurveda, jointly circulating the protective guidelines and protocol in the India first time to defect this deadly infectious disease. Various Institutions are doing Clinical trials on COVID-19 by using Samsamni Vati, Sudersan Curna, Ayush Kwatha, Anu-taila Nasya, and other Ayurvedic formulation. Different Immunity booster medicines like Chyawanprash, turmeric milk, and Holy basil tablet are used to improve immunity. State Ayush services dispense the immunity booster kit to Frontline workers/fighters like medical \& health care personal, police force, and the general public.

\section{REFERENCES}

1. Cucinotta, D., \& Vanelli, M. (2020). WHO declares COVID-19 a pandemic. Acta bio-medica: Atenei Parmensis, 91(1), 157-160.

2. Chaturvedi, G. N., Sastri, K. N., \& Sutra, S. (2005). Vidyotini Hindi commentary on Charak Samhita of Agnivesa, Chaukhamba Bharti Academy, Varanasi, India, Edition 2005, verse 30/11, 583.

3. Chaturvedi, G. N., \& Sastri, K. N. (2005). Vidyotini Hindi commentary on Charak Samhita of Agnivesa, Chaukhamba Bharti Academy, Varanasi, India Edition 2005, Vimana Sthana, verse 3/5, 568.

4. Yang, H., Bartlam, M., \& Rao, Z. (2006). Drug design targeting the main protease, the Achilles' heel of coronaviruses. Current pharmaceutical design, 12(35), 4573-4590.

5. Ananthanarayan \& Pannikar, Textbook of Microbiology, 8th edition, 556.
6. Padhi, A., Kumar, S., Gupta, E., \& Saxena, S. K. (2020). Laboratory Diagnosis of Novel Coronavirus Disease 2019 (COVID-19) Infection. In Coronavirus Disease 2019 (COVID-19) (pp. 95-107). Springer, Singapore.

7. Tsang, O. T. Y., Chau, T. N., Choi, K. W., Tso, E. Y. K., Lim, W., Chiu, M. C., ... \& Lai, J. Y. (2003). Severe acute respiratory syndrome: relapse? Hospital infection?. Emerging infectious diseases, 9(9), 1180-81.

8. Tsang, O. T. Y., Chau, T. N., Choi, K. W., Tso, E. Y. K., Lim, W., Chiu, M. C., ... \& Lai, J. Y. (2003). Severe acute respiratory syndrome: relapse? Hospital infection?. Emerging infectious diseases, 9(9), 1180.

9. Shastri, A. (2009). Ayurvedatatvasandipika Hindi commentary on Susruta Samhita, Chaukhamba Sanskrit Sansthan, Varanasi, India, Edition 2009, Uttar Tantra, verse $1 / 25,14$.

10. Shastri, A. (2009). Ayurvedatatvasandipika Hindi commentary on Susruta Samhita, Chaukhamba Sanskrit Sansthan, Varanasi, India, Edition 2009, Sutra Sthana, verse 6/22, 31.

11. Shastri, A. (2007). Ayurvedatatvasandipika Hindi commentary on Susruta Samhita, Chaukhamba Sanskrit Sansthan, Varanasi, India Part-I, Chaukhamba Sanskrit Sansthan, 2007, 18.

12. Chaturvedi, G. N., \& Sastri, K. N. (2005). Vidyotini Hindi commentary on Charak Samhita of Agnivesa, Chaukhamba Bharti Academy, Varanasi, India, Edition 2005, Sutra Sthana, verse $1 / 58,35$.

13. Chaturvedi, G. N., \& Sastri, K. N. (2005). Vidyotini Hindi commentary on Charak Samhita of Agnivesa, Chaukhamba Bharti Academy, Varanasi, India, Edition 2005, Sutra Sthana, verse 11/35, 227.

14. Sharma, H. (2013). Vidyotini Hindi Commentary on Kashyap Samhita of Vrddhajivaka, Chaukhambha Sanskrit Sansthan, Varanasi, Edition Reprint 2013, Khill Sthana, verse 4/6, 249.

15. Sharma, H. (2013). Vidyotini Hindi Commentary on Kashyap Samhita of Vrddhajivaka, Chaukhambha Sanskrit Sansthan, Varanasi, India, Edition 2013, Khill Sthana, verse 4/5, 249.

16. Abel, A. N., Lloyd, L. K., \& Williams, J. S. (2013). The effects of regular yoga practice on pulmonary function in healthy individuals: a literature review. The Journal of Alternative and Complementary Medicine, 19(3), 185-190.

17. Morgan, N., Irwin, M. R., Chung, M., \& Wang, C. (2014). The effects of mind-body therapies on the immune system: meta-analysis. PloS one, 9(7), e100903.

18. Maxwell, L., Barrett, B., Chase, J., Brown, R., \& Ewers, T. (2015). Self-reported mental health predicts acute respiratory infection. WMJ: official publication of the State Medical Society of Wisconsin, 114(3), 100. 